ment' myrmekites renders it likely that allied processes would interact with exsolution, particularly where the two myrmekite types formed essentially simultaneously (HuntlyPortsoy area).

Perhaps the most serious weakness of a non-Schwantke exsolution-driven hypothesis arises from the fact that the pore-fluid in a metamorphic rock constitutes a very small proportion of the bulk system. The amount of interacting fluid required might be such that a large body of rock would be involved, and metasomatism could no longer be maintained to be 'small-scale'.

However, it is possible that a more bulky fluid may sometimes participate. I fear that my use of the word 'fluid' has caused confusion; I meant it as a neutral term to avoid specific nomination of either an aqueous fluid or a silicate melt. The possible presence of a relatively large amount of the latter during early myrmekite formation must be taken seriously in granitic and migmatitic rocks. It is likely that in some cases this fluid was available for an interactive reaction of the type discussed in Section 7 of Ashworth (1972).

In summary, a non-Schwantke exsolution-dominated hypothesis for myrmekite formation remains tenable, but requires a bulky and/or mobile fluid medium, which should be better defined before the hypothesis can be discussed adequately. The existence of myrmekites formed by several retrograde reactions under different conditions, in addition to those formed by exsolution or exsolution-dominated processes, reinforces the need to consider controls that could lead to the characteristic features of the intergrowth and are more generally applicable than the possible existence of Schwantke solid solution.

Department of Physics

J. R. ASHWORTH

University of Essex

Wivenhoe Park

Colchester CO4 3SQ.

21 st November 1972

\title{
Ordovician stratigraphy of Abereiddy Bay, Pembrokeshire
}

SIR,-The recent debate (Waltham, 1971; Black et al., 1972) on the Ordovician stratigraphy of Abereiddy Bay, Pembrokeshire, with its relevance to the work of the late Professor A. H. Cox, lends interest to some of the modifications of his earlier views that Professor Cox intended to publish in the later years of his lifetime of research into the geology of Pembrokeshire.

Following periods of field work in the late nineteen forties Professor Cox wrote for the Geological Survey, in about 1950-51, the outline of a 'memoir' on the geology of the St David's area and, on pp. 142-5 of our copy of his Ms, he discussed the Ordovician sequence on the north side of Abereiddy Bay. Referring to the section in the old tramway cutting that enters the south side of Porth Gain Quarry Professor Cox wrote:

'The apparent sequence exposed along this cutting from north to south is: Llandeilo Flags with many trilobites, and black graptolitic shales; Castell Limestone-dark greyblue limestone with partings of graptolitic black shale with trilobites and corals; Black shales-Dicranograptus Beds.

'Observed dips are consistently north at $50^{\circ}-60^{\circ}$. When this section was first observed it was believed, in view of the persistently northern dip, that the sequence in the limestone was a normal sequence and that the Llandeilo Flags were introduced by a fault. More recently Dr Robertson, in the course of a visit, expressed his belief that the whole sequence was inverted, basing his opinion on the relations between bedding and cleavage, the cleavage dip being at a much smaller angle than the bedding dip. This conception of an inverted dip helped to a more harmonious reading of the sequence. 
'The Castell Limestone, which appears to dip north at $50^{\circ}-60^{\circ}$ beneath the Llandeilo Flags, but is actually inverted is, in its unweathered state, dark grey-blue in colour. The individual limestone bands are rather variable, some being fine grained, massive and very uniform; others are more shaly, while others are more arenaceous. The limestone includes interbedded bands of shale up to $3 \mathrm{ft}$ in individual thicknesses. The limestone group with its included shales is about $50 \mathrm{ft}$ thick, and the apparent dips on the shore are $50^{\circ}$ to NNW, but nearer $60^{\circ}$ at the quarry entrance.'

(Then follows a faunal list)

'The graptolites fix the horizon of this limestone as about the same as that of the Mydrim Limestone of Carmarthenshire with which it also compares in lithology. An exact lithological comparison, and also the same type of Orthids, were found in the small limestone knob of Ty pica which rises from beneath the alluvial plain of the River Towy, Llandeilo.

'Somewhere to the south (of Porth Gain Quarry) there must be an overfold or more probably a fault which terminates the overturned beds and introduces the normal northward-dipping Llandeilo shales seen on the south side of the bay.'

It is clear from the above that by 1950 Professor Cox had abandoned the three tenets on which his work is now criticized, i.e. (1) that the sequence ascends from south to north, (2) that a near-invisible thrust-fault bounds the Castell Limestone, and (3) that the 'overlying' trilobite-bearing beds are of $D$. bifidus Beds age. Unfortunately Professor Cox's Ms was never worked up into proper memoir format and hence remained unpublished. His reference to 'Dr Robertson' is of course to Dr T. Robertson of Ullapool who was then Asssistant Director (England and Wales) of the Geological Survey, and who appears to have been the first, by many years, to recognize the inverted character of the sequence north of Abereiddy Bay. Sciences.

This letter is published by permission of the Director, Institute of Geological

\section{References}

Black, W. W., Bulman, O. M. B., Hey, R. W., Hughes, C. P. \& Waltham, A. C. 1972. Ordovician Stratigraphy of Abereiddy Bay, Pembrokeshire. Geol. Mag. 108, 546-8.

Waltham, A. C. 1971. A note on the structure and succession at Abereiddy Bay, Pembrokeshire. Geol. Mag., 108, 59-52.

Institute of Geological Sciences

J. R. EARP

5 Princes Gate

London SW7

21st July 1972

\section{Time scale and ice accumulation during the last 125,000 years as indicated by Greenland $\mathrm{O}^{18}$ curve}

SIR,-In a recent paper in this journal Mörner (1972) has strongly criticized the depthage relationships applied to the deep ice core from Camp Century, Greenland (Dansgaard et al., 1969, 1971). It is argued that logarithmic time scales must be wrong, because the ice flow parameters have changed during the last 125,000 years.

We are unable to see any relationship between Dr Mörner's criticism and our 1971 paper. For example, the time scale is not logarithmic. It is clearly stated to be 'independent of the $\mathbf{C}^{14}$ scale, of all ice flow parameters, and of their possible temporal changes' (p. 53). For the same reason, Dr Mörner's attempt to use the isotope curve to determine temporal accumulation changes makes no sense. A warning against this was stressed on 